\title{
Influence of the total concentration and the profile of volatile fatty acids on polyhydroxyalkanoates (PHA) production by mixed microbial cultures
}

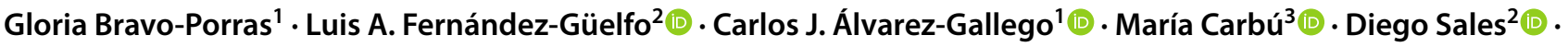 \\ Luis I. Romero-García ${ }^{1}$ (D)
}

Received: 29 September 2021 / Revised: 24 November 2021 / Accepted: 5 December 2021

(c) The Author(s) 2021

\begin{abstract}
Polyhydroxyalkanoates (PHAs) production from lignocellulosic biomass using mixed microbial cultures (MMC) is a potential cheap alternative for reducing the use of petroleum-based plastics. In this study, an MMC adapted to acidogenic effluent from dark fermentation (DF) of exhausted sugar beet cossettes (ESBC) has been tested in order to determine its capability to produce PHAs from nine different synthetic mixtures of volatile fatty acids (VFAs). The tests consisted of mixtures of acetic, propionic, butyric, and valeric acids in the range of 1.5-9.0 g/L of total acidity and with three different valeric:butyric ratios (10:1, 1:1, and 1:10). Experimental results have shown a consistent preference of the MMC for the butyric and valeric acids as carbon source instead other shorter acids (propionic or acetic) in terms of PHA production yield (estimated in dry cell weight basis), with a maximum value of $23 \% \mathrm{w} / \mathrm{w}$. Additionally, valeric-rich mixtures have demonstrated to carry out a fast degradation process but with poor final PHA production compared with high butyric mixtures. Finally, high initial butyric and valeric concentrations $(1.1 \mathrm{~g} / \mathrm{L}$ and $4.1 \mathrm{~g} / \mathrm{L})$ have demonstrated to be counterproductive to PHA production.
\end{abstract}

Keywords Polyhydroxyalkanoates $\cdot$ Bioplastic $\cdot$ Volatile fatty acids $\cdot$ Mixed microbial cultures

\section{Introduction}

Polyhydroxyalkanoates (PHAs) are bio-polyesters synthesized intracellularly by some microorganisms. Its main function is to serve as a carbon and energy reserve in stressful situations in which the growth of microorganisms is unfavorable (inadequate balance of nutrients, scarcity of carbon sources, heat stress, etc.) $[1,2]$. Their main practical application is based on the fact that they present physical properties

Carlos J. Álvarez-Gallego

carlosjose.alvarez@uca.es

Gloria Bravo-Porras

gloria.bravo@alum.uca.es

Luis A. Fernández-Güelfo

alberto.fdezguelfo@uca.es

María Carbú

maria.carbu@uca.es

Diego Sales

diego.sales@uca.es

Luis I. Romero-García

luisisidoro.romero@uca.es similar to certain plastics derived from petroleum. For this reason, there is a growing interest in the industrial sector for their production since they are precursors of plastics with excellent biocompatibility characteristics and biodegradability [3]. Moreover, these polymers are thermoplastic and/ or elastomers, insoluble in water, and have a high polymerization degree. They are also pure compounds in relation to their enantiomeric structure; are non-toxic and biocompatible; have a high crystallinity degree (between 60 and

Department of Chemical Engineering and Food Technology, Faculty of Science, International Campus of Excellence (ceiA3), University of Cadiz, Puerto Real, 11510 Cádiz, Spain

2 Department of Environmental Technologies, Faculty of Marine and Environmental Sciences, International Campus of Excellence (ceiA3), University of Cadiz, Puerto Real, 11510 Cádiz, Spain

3 Department of Biomedicine, Biotechnology and Public Health, Microbiology Laboratory, Faculty of Marine and Environmental Sciences, International Campus of Excellence (ceiA3), University of Cadiz, Puerto Real, 11510 Cádiz, Spain 
$80 \%)$; are optically active; and also exhibit piezoelectric properties. These properties make them especially interesting to replace some plastics derived from petroleum; more specifically, they agree in properties in a very relevant way with polypropylene [1, 4].

The main advantage of PHA polymers over petroleumderived plastics is that they are biopolymers that can be produced from vegetal biomass and even from various kinds of organic wastes. Their chemical structure makes them easily biodegradable both in soils and in aqueous environments through aerobic or anaerobic degradation processes [5, 6]. All this implies that they are not materials harmful to the environment being, therefore, a sustainable product obtained from renewable materials that replaces plastics from fossil sources [7].

Despite the great advantages that PHAs have over petroleum-derived plastics, their current use is very limited due to their high production cost, which is largely attributed to the use of carbonaceous substrates of industrial interest. In addition, the most studied PHA production processes focus on the use of pure strains of microorganisms, such as Cupriavidus necator, that presents a high PHA accumulation yield in dry weight but increases the production costs due to the requirements to avoid the contamination with other microorganisms [8-11]. As a more economical alternative, some authors have proposed the use of wastewater, wastes, and residual biomass as cheap carbon sources for the process [7]. It is also possible to make the process cheaper by using mixed microbial cultures (MMC) instead of pure cultures, although PHA productivity declines notably [1, 12-14]. In addition, the diversity of microorganisms in MMC could lead to biopolymers with non-defined properties since each microorganism can produce different PHA monomers [15].

Volatile fatty acids (VFAs) are excellent substrates for the production of PHA by MMC [16]. Therefore, the utilization of the dark fermentation (DF) process to obtain VFAs from different biomass waste is a very interesting option for the aerobic production of PHAs [7, 17, 18]. Thus, acidogenic anaerobic digestion (AAD) or commonly DF is a variation of the classic biological process of anaerobic digestion in which the stages that involve methanogenesis do not occur since operating conditions are used to prevent it. Thus, the microorganisms involved in DF transform organic matter into short-chain volatile fatty acids (VFAs) and produce biogas rich in carbon dioxide and mainly hydrogen $[19,20]$.

With regard to the VFAs profile, the proportion between the different acids has a great influence on the mechanical properties of the final plastics and their subsequent industrial application. In the PHA production with MMC, acetic and butyric acids favor the production of 3-hydroxybutyrate (3HB) while propionic and valeric acids promote the synthesis of 3-hydroxyvalerate (3HV) [16, 21]. Poly(3-hydroxybutyrate) $(\mathrm{P}(3 \mathrm{HB}))$ is brittle and rigid and therefore has limited industrial applications. However, the incorporation of $3 \mathrm{HV}$ into $\mathrm{P}(3 \mathrm{HB})$ leads to the formation of the copolymer $\mathrm{P}$ (3HB-co-3HV), which is more flexible and harder. In addition, the latter is less permeable to oxygen compared to polyethylene and commercial polypropylene, making it a suitable material for food packaging.

Among the various types of residual biomass that can be used for the biosynthesis of PHAs, exhausted sugar beet cossettes (ESBC) have been chosen in this study to develop an inoculum enriched in PHA producers. The ESBC is generated during the sugar extraction process from sugar beet and it is an agrifood byproduct with a low lignin content [22]. In this context, the objective of this work is to study the influence of the VFAs profile and the total acidity concentration on the PHA yield using a MMC as inoculum coming from a sequential process coupling DF and aerobic PHA production that used ESBC as substrate. To study the influence of these variables on the PHA production, synthetic mixtures of VFAs were used.

This study reveals the existence of some counterproductive limits to PHA production by MMC linked to the presence of high concentrations of valeric and butyric acids. Likewise, the study shows as the ratio between butyric and valeric acids affects PHA yield.

\section{Materials and methods}

To address the proposed objective, three sets of batch tests have been carried out with 1L-bioreactors fed with a mixture of synthetic acids, simulating the VFAs profile typical of the DF of ESBC but modifying the proportions of valeric and butyric acids. The batch tests have been carried out in duplicate. Nine different conditions were studied modifying the valeric:butyric ratio and the total volatile acidity as it is showed in Table 1.

Table 1 Nomenclature applied to identifying assays and experimental conditions

\begin{tabular}{lll}
\hline Code & $\begin{array}{l}\text { Total VFAs concentration }(\mathrm{g} \\
\text { HAc/L) }\end{array}$ & $\begin{array}{l}\text { Valeric:butyric } \\
\text { ratio }\end{array}$ \\
\hline $1.5 \mathrm{~B}$ & 1.5 & $1: 10$ \\
$2.5 \mathrm{~B}$ & 2.5 & $1: 10$ \\
$3.5 \mathrm{~B}$ & 3.5 & $1: 10$ \\
$3.0 \mathrm{~N}$ & 3.0 & $1: 1$ \\
$3.5 \mathrm{~N}$ & 3.5 & $1: 1$ \\
$5.0 \mathrm{~N}$ & 5.0 & $1: 1$ \\
$5.0 \mathrm{~V}$ & 5.0 & $10: 1$ \\
$7.0 \mathrm{~V}$ & 7.0 & $10: 1$ \\
$9.0 \mathrm{~V}$ & 9.0 & $10: 1$ \\
\hline
\end{tabular}




\subsection{Obtaining the PHA-producing inoculum}

The inoculum used in the batch tests comes from a sequential system of two semi-continuous reactors coupled in series.

The first reactor is a $5 \mathrm{~L}$-anaerobic and thermophilic stirred tank reactor $\left(55^{\circ} \mathrm{C}\right)$ which has been fed with ESBC that produces hydrogen-rich biogas and a VFA-rich effluent (acetic, propionic, butyric, valeric, etc.). The reactor was started from an anaerobic reactor that operated under methanogenic anaerobic digestion conditions. In this reactor, to produce the complete washing of the methanogenic microbiota in 21 days, a strategy of reducing the hydraulic retention time (HRT), from 18 to 6 days, and the $\mathrm{pH}$ until 5.5 as set point was applied. This reactor was in stable operation for more than 250 days with an average production of biogas (hydrogen and carbon dioxide) at the moment to perform the batch tests over $1.5-2.0 \mathrm{~L} / \mathrm{L}_{\text {reactor }}$.day and with an average hydrogen percentage of $30-40 \% \mathrm{v} / \mathrm{v}$ in the biogas.

The liquid fraction of the acidogenic effluent from this first reactor was used to feed a second reactor destined for the PHA production, with a stable population of microorganisms selected from mixed sludge from a wastewater treatment plant (WWTP). A solution of nutrients recommended in the literature was added to this liquid fraction to enhance the PHA production [23]. The total volatile acidity concentration in the acidogenic effluent was maintained in the range of $10-20 \mathrm{~g} \mathrm{HAc} / \mathrm{L}$.

In the second 5L-reactor for the PHA production, a microbiota capable of producing PHAs was selected, applying a strategy based on alternating oxic and anoxic periods of $24 \mathrm{~h}$, coinciding with periods of scarcity and abundance of the substrate (famine-feast cycles). During the oxic periods, the soluble oxygen concentration was kept between 6 and $8 \mathrm{mg} / \mathrm{L}$. The operating HRT, which was initially set at 12.5 days, was reduced to 9 days once the selection of the PHA-producing microbiota was made to increase the rate of the process. Throughout this process to obtain a stable PHA-producing inoculum, the PHA production yields were among 20-40 mg PHA/L, with values close to $60 \mathrm{mg}$ PHA/L (13\% dry cell weight) when it was used for the inoculation of batch reactors. The reduction of organic matter, in terms of soluble chemical oxygen demand (COD), was around $90-95 \%$ with an organic loading rate of $2.5 \mathrm{~g} \mathrm{COD} /$ $\mathrm{L}_{\text {reactor }}$.day at the moment in which it was used as inoculum for the start-up of the batch tests.

\subsection{Study of the effect of total acidity and the VFA profile on the PHA production}

To carry out this study, nine duplicated tests were carried out operating in batch mode and using 1-L reactors with a 50:50 (v/v) substrate to inoculum ratio. The inoculum used comes from the inoculation PHA reactor described in the previous section. The substrate was composed of a synthetic mixture of acetic, propionic, butyric, and valeric acids in a nutrient solution previously indicated. All the trials were performed by combining these conditions according to Table 1. Albuquerque et al. [24] have reported that no significant variations were observed in terms of PHA yield, maximum PHA content, and PHA composition between the synthetic and fermented feedstocks.

At the inoculation time, in the effluent from the acidogenic reactor, the average proportions of acids were 83.2:1.0:43.9:2.0 in terms of acetic:propionic:butyric:valer ic, respectively. In all the synthetic mixtures, concentrations of acetic and propionic acids were incorporated in the same proportion of the acidogenic effluent obtained from the DF reactor but modifying the proportions between butyric and valeric acids, with respect to their original proportion with acetic acid, in order to obtain the valeric:butyric ratios to be tested $(10: 1 ; 1: 1$; and $1: 10)$.

Given the results obtained for the first set of assays with high butyric acid proportion, it was decided to modify the initially planned experimental set up in the study. Thus, it was decided to check, in the second set of assays (neutral ratio assays), a range of total acidity concentrations higher than the previous ones $(1.5-3.5 \mathrm{~g} / \mathrm{L})$ but maintaining the butyric acid concentration lower than $1 \mathrm{~g} \mathrm{HBu} / \mathrm{L}$.

Finally, for the third set of assays (high valeric assays), it was considered appropriate to continue increasing the total volatile acidity concentration but limiting the presence of butyric acid in order to analyze the independent influence of valeric acid on the PHA production in a more evident way.

Each set of tests consisted of six reactors (three conditions by duplicate) with synthetic mixtures. The tests have been carried out at $25^{\circ} \mathrm{C}$ and with a constant aeration rate of $20 \mathrm{~L}_{\text {air }} / \mathrm{L}_{\text {reactor }} \cdot \mathrm{h}$ in order to maintain an oxic environment and to promote the PHA production. The system used the forced aeration itself for homogenizing the content of the reactors.

\subsection{Analytical techniques}

The analytical determinations were carried out according to the standard methods for wastewater [25] adapted to high organic content waste. For the monitoring of the reactors, the following parameters were analyzed: $\mathrm{pH}\left(4500-\mathrm{H}^{+}\right)$, dissolved oxygen (DO) (4500-O), volatile suspended solids (VSS) (2540-B/E), COD (5220-C), and dissolved organic carbon (DOC) (5310-B).

For the determination of DO, an oximeter (Labprocess ${ }^{\circledR}$ OXY 70) was used based on an optical luminescence cell. The DOC was determined by means of a carbon analyzer (Analytik Jena ${ }^{\circledR}$ multi N/C 3100) with samples previously filtered by $0.47 \mu \mathrm{m}$.

Additionally, the quantification of the total PHA concentration was performed by UV spectrophotometry at $235 \mathrm{~nm}$ 
after an extraction process according to the procedure described in the literature [26, 27].

The individual VFAs were measured by gas chromatography in a Shimadzu ${ }^{\circledR}$ GC-2010 equipped with a flame ionization detector (FID) and a fixed phase column of the Nukol ${ }^{\circledR}$ type (polyethylene glycol modified with terephthalic acid). Hydrogen was used as carrier gas at a flow rate of $50 \mathrm{~mL} /$ $\mathrm{min}$. The temperature of the injection port and the detector were $200{ }^{\circ} \mathrm{C}$ and $250{ }^{\circ} \mathrm{C}$, respectively [28].

The biogas generated by the acidogenic anaerobic reactor was collected in Tedlar ${ }^{\circledR}$ gas bags (SKC $® 232$ series) and it was quantified using a wet rotary drum gas flow meter (Ritter ${ }^{\circledR}$ TG5) connected to a Laboport gas suction pump (KNF®, model KT18) with a capacity of $5.5 \mathrm{~L} / \mathrm{min}$ under standard conditions of pressure and temperature. The biogas composition from the acidogenic anaerobic reactor was determined by a gas analyzer EMERSON® X-Stream.

\subsection{Inoculum}

PHA-producers bacteria have been identified in the effluent of the PHA inoculum reactor. For that, the sample was serially diluted and plated on LB (Luria-Bertani) and VKM culture medium. VKM medium contained acidogenic effluent:nutrient solution:distilled water, 3:4:3 ratio, supplemented with yeast extract $(1 \mathrm{~g} / \mathrm{L})$ and agar $(25 \mathrm{~g} / \mathrm{L})$. The plates were incubated at $25{ }^{\circ} \mathrm{C}$ for 7 days. For each medium, several representative types of colonies were identified and purified after several passages on the same type of medium.

The most representative colonies were isolated and genomic DNA was extracted following the protocol described by Saba et al. [29]. The isolates were typed by sequencing the 16S rRNA gene that had been amplified by PCR from genomic DNA [30]. Similarity searches were performed with the Basic Local Alignment Search Tool (BLAST) [31] on the DNA sequences with the Genbank ${ }^{\circledR}$ database.

\section{Results and discussion}

\subsection{Verification of the presence of PHA producers in the inoculum}

A total of 20 bacteria were isolated from the PHA production bioreactor. The $16 \mathrm{~S}$ ribosomal RNA sequences of the isolates were matched with the contents of the databank by Nucleotide BLAST. At a percent identity score of $\geq 97 \%$, a total of 8 different bacteria genera were identified: Agrococcus (98.4\%), Corynebacterium (97.2\%), Cupriavidus (97.5\%), Enterobacter (98.9\%), Microbacterium (98.9\%), Salana (97.1\%), Stenotrophomonas (99.7\%), and Pseudoclavibacter (99.1\%). Cupriavidus $(\mathrm{n}=6$ isolates tested) was the most common genus in the inoculum, followed by Corynebacterium $(\mathrm{n}=5)$ and Enterobacter $(\mathrm{n}=4)$, while Salana, Pseudoclavibacter, Agrococcus, Stenotrophomonas, and Microbacterium were identified in one isolate. Of these, the genera Enterobacter [32], Corynebacterium [33], Cupriavidus [34, 35], and Microbacterium [36, 37] have been previously described as PHA producers. In addition, Cupriavidus necator is the most widely used Gram-negative bacterium due to its high PHA production capacity [8].

\section{$3.2 \mathrm{pH}$ and oxygen}

Except on day 0 (start-up) when some reactors had $\mathrm{pH}$ below 7 , which was immediately corrected, the $\mathrm{pH}$ values always remained in a very stable range between 8 and 9, with a slight trend to increase. This range of values agrees with data reported by Chua et al. [38] using batch reactors fed with urban wastewaters.

On the other hand, DO concentration showed the opposite behavior to the PHA accumulation, decreasing gradually as the VFAs were consumed (see Sect. 3.3). Thus, the lowest values were reached when PHA production peaked while the initial DO level was recovered once the microorganisms begin to consume the PHAs formed due to a shortage of other available carbon sources. Similar results were obtained by Mannina et al. [13] working with acetic- and acetic-propionic-based feedings.

In order to illustrate this behavior, the evolution of $\mathrm{pH}$, DO oxygen, and PHA production in the assay called 1.5B has been selected to be shown in Fig. 1. The rest of the tests have similar evolutions of the mentioned parameters.

\subsection{Organic matter removal}

This section presents the evolution of COD, DOC, and total volatile acidity as representative parameters of the organic matter available for the PHA production in the batch tests.

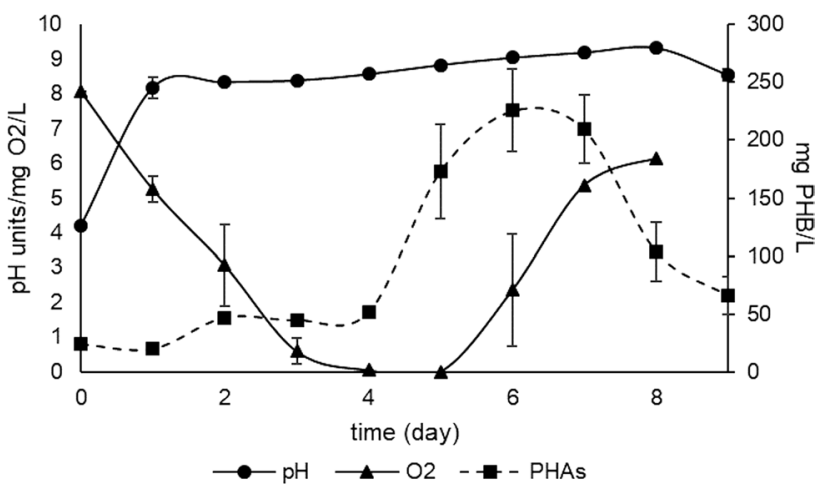

Fig. $1 \mathrm{pH}$ in $\mathrm{pH}$ units, $\mathrm{DO}$ in $\mathrm{mg} \mathrm{O}_{2} / \mathrm{L}$, and $\mathrm{PHA}$ production expressed as $\mathrm{mg} \mathrm{PHB} / \mathrm{L}$ evolutions for the assay $1.5 \mathrm{~B}$ 
Figure 2 shows the evolution of the COD in the reactors grouped by the valeric:butyric ratio. All evolutions show a clear decreasing trend except for the assay named 3.5B where the decrease was slow and weak and, hence, as far as the trial progresses, the amount of organic matter is lower due to the degradative activity of the microorganisms.

However, the diminishing does not occur in the same way for tests that have the same valeric:butyric ratio but different total volatile acidity concentration. In general, the decline is rapid (reaching the final levels in 6-8 days) except for test

(a)

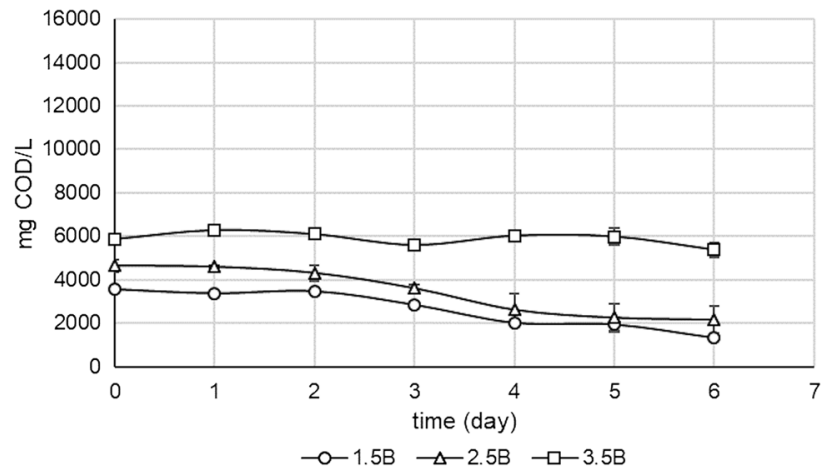

(b)

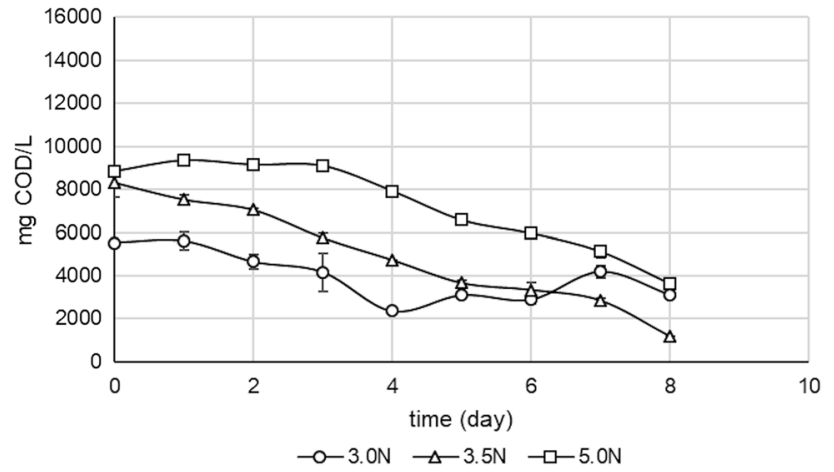

(c)

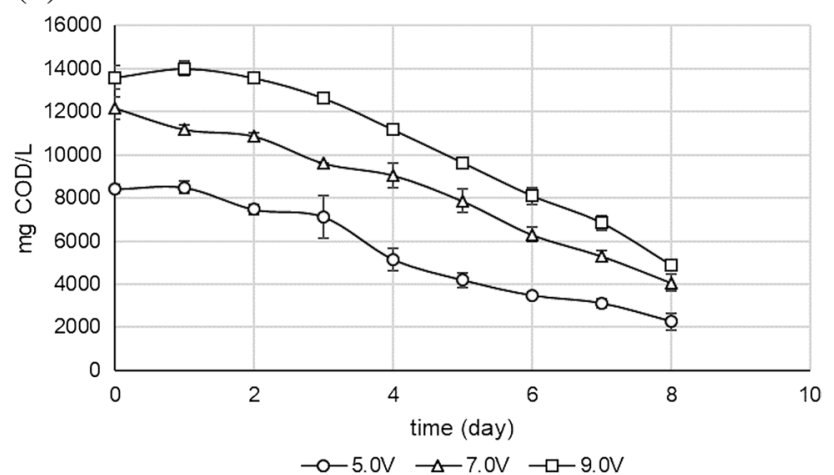

Fig. 2 Total COD evolution expressed in $\mathrm{mg} \mathrm{O}_{2} / \mathrm{L}$. a Assays with 1:10 valeric:butyric ratio; $\mathbf{b}$ assays with $1: 1$ valeric:butyric ratio; $\mathbf{c}$ assays with $10: 1$ valeric:butyric ratio
3.5B where the high butyric acid concentration seems to be a problem for COD reduction. The literature [39] indicates that if $C$. necator has optimal growth conditions (including enough carbon and nutrient sources), the acetyl-CoA is massively incorporated into the Krebs cycle. This metabolic process involves great CoA production. Consequently, the excess of CoA inhibits the actuation of 3-ketothiolase (the enzyme related to acetoacetyl-CoA production which is the first step in the PHA production pathway). Therefore, in optimal condition, the PHA production could be stopped in the first step [39]. An increase in substrate concentration could derive in a PHA production inhibited by the substrate as some authors have confirmed [40-43]. While the other assays with the same ratio valeric:butyric (1.5B and $2.5 \mathrm{~B}$ ) reduce their concentrations to less than half in 4 days, in the $3.5 \mathrm{~B}$ trial, the degradation is weak and delayed. Nevertheless, when the proportion of valeric acid is highest $(5.0 \mathrm{~V}$, $7.0 \mathrm{~V}$, and $9.0 \mathrm{~V}$ ), the degradation is still fast and very uniform even when the total volatile acidity increases. This fact shows that the system presents a lower sensitivity to high valeric acid concentrations (up to $4 \mathrm{~g} / \mathrm{L}$ in assay $9.0 \mathrm{~V}$ ) as it will be seen in the following sections.

The other two parameters related to available organic matter that have been analyzed are DOC and total volatile acidity. Their evolutions are shown in Figs. 3 and 4, respectively. As for the previous COD graphs, the results have also been grouped by their valeric:butyric ratio.

In a much more evident way than in the case of COD, a gradual decrease in DOC concentration has been observed. It should be noted that the final levels after 8-9 days are very similar regardless of the initial concentration of total volatile acidity (419-453 $\mathrm{mg} \mathrm{C/L}$ and $183-227 \mathrm{mg} \mathrm{C} / \mathrm{L}$ in assays $\mathrm{V}$, and $\mathrm{N}$, respectively), except for the highest butyric concentration assay (503 $\mathrm{mg} \mathrm{C} / \mathrm{L}$ in $3.5 \mathrm{~B}$ versus $93-179 \mathrm{mg}$ $\mathrm{C} / \mathrm{L}$ in $1.5 \mathrm{~B}$, and $2.5 \mathrm{~B}$, respectively). This test, as it was previously noted in the COD evolution, seems to have different behavior and it could have developed an incomplete substrate degradation for the duration of the test. Moreover, the 3.5B test also showed an initial period of 4-5 days with a notably lower COD consumption rate than the other tests.

In the case of the total volatile acidity, determined as the weighted sum of the concentrations of individual VFAs (C2-C7) and expressed in units of mg HAc/L, decreasing is gradual and clear. VFAs are the ultimate substrate that would lead to the PHA production.

It could be observed that high valeric acid concentration assays (Fig. 4c) have shown a sharper and more continuous VFAs degradation rate than high butyric (Fig. 4a) and neutral ratio assays (Fig. 4b). Thus, a much more uniform trend can be observed for the degradation of total volatile acidity in the high valeric acid content assays.

As it was observed for COD and DOC evolutions, the behavior of the 3.5B test is also differentiated. In fact, VFAs 
(a)

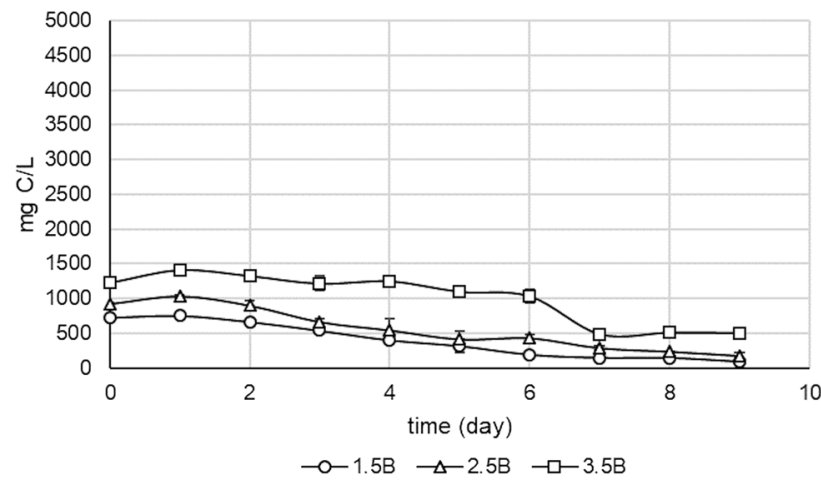

(b)

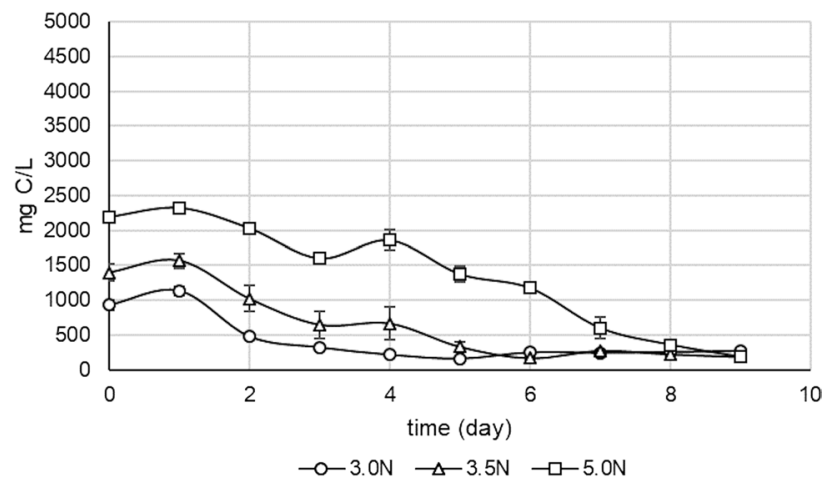

(c)

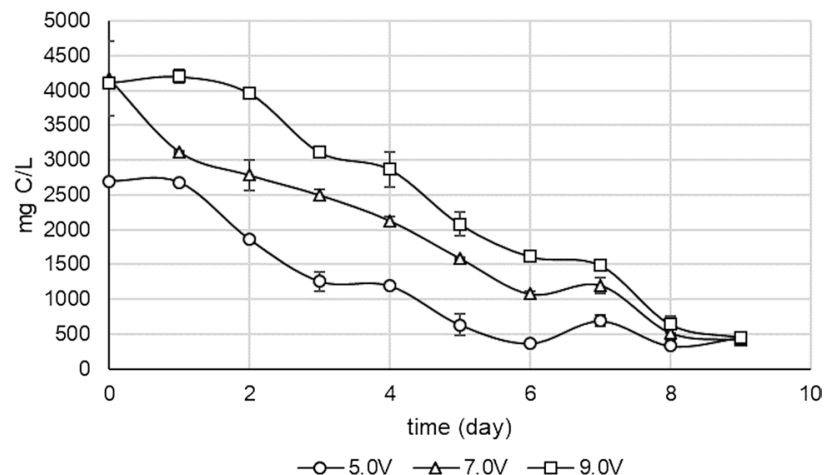

Fig. 3 DOC evolution expressed in $\mathrm{mg}$ C/L. a Assays with 1:10 valeric:butyric ratio; $\mathbf{b}$ assays with 1:1 valeric:butyric ratio; $\mathbf{c}$ assays with $10: 1$ valeric:butyric ratio

degradation was slower and delayed in 3.5B compared with $1.5 \mathrm{~B}$ and $2.5 \mathrm{~B}$.

In short, the analysis of DOC, COD, and total volatile acidity denotes that all the tested conditions, except 3.5B which corresponds to the highest butyric acid concentration, have been successful in removing a high proportion of organic matter in a very short time. (a)

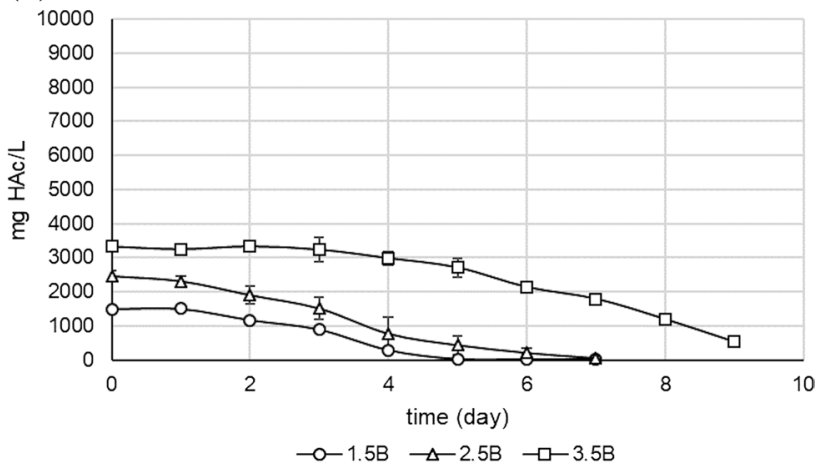

(b)

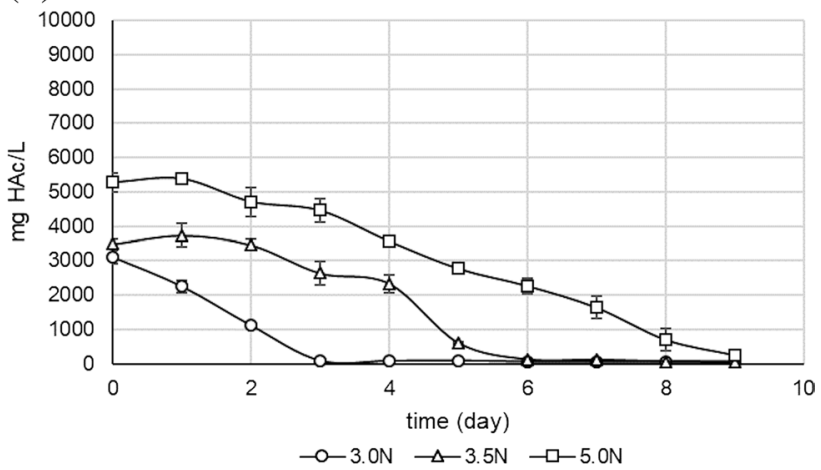

(c)

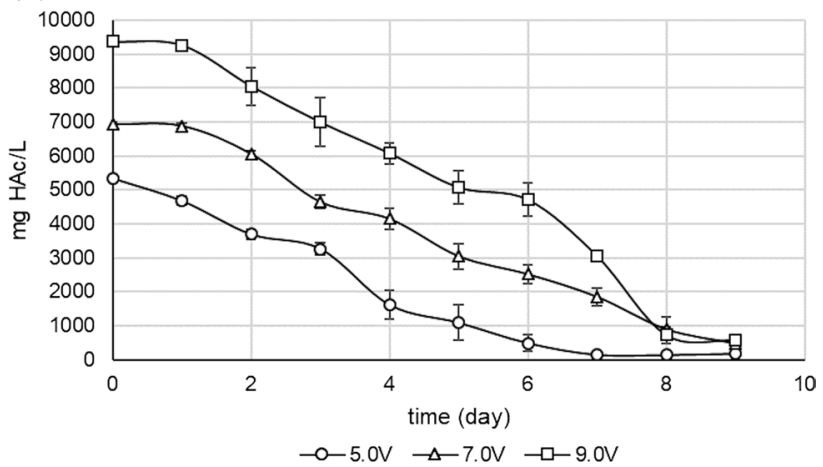

Fig. 4 Total volatile acidity evolution expressed in mg HAc/L. a Assays with 1:10 valeric:butyric ratio; b assays with 1:1 valeric:butyric ratio; $\mathbf{c}$ assays with 10:1 valeric:butyric ratio

\subsection{PHA production coupled to VFA consumption}

The analysis of the individual evolution of the four VFAs used in the synthetic feed allows observing how their consumption is coupled to the PHA production. For each condition, a graph has been built in order to analyze how the total volatile acidity and valeric:butyric ratio influence the PHA production (see Fig. 5). 


\subsubsection{High butyric assays (1.5B, 2.5B, and 3.5B and Fig. 5a, $5 b$, and $5 c$ )}

Acetic and butyric are major acids at the beginning of the assays. Both acids have been gradually degraded until PHAs, reaching a maximum PHA production around day 6 for the tests with the lowest total volatile acidity (1.5B and $2.5 \mathrm{~B}$ ). From day 6 , the microorganisms in the absence of a carbon source started to degrade the formed PHA for their cellular maintenance and catabolic needs [2].

However, the test 3.5B has shown a differentiated behavior. In this case, there are evident difficulties to begin to degrade the butyric acid, which remains above the level of $1100 \mathrm{mg} / \mathrm{L}$ for 4 days. As consequence, a delay in the PHA production takes place. Once the degradation of butyric acid starts, PHA production increases and reaches a maximum value around day 8 .

Before day 4, PHA production seems to be coupled almost exclusively to acetic acid consumption. It seems evident that the presence of high butyric acid concentrations has partially inhibited the PHA production by slowing down the whole process. In this sense, Wang et al. [43] had already established that under high initial concentrations of short-chain VFAs (C2-C4), the growth of $C$. necator was markedly impaired. In their kinetic analysis, they established the onset of inhibition at $125 \mathrm{Cmmol}$ of total volatile acidity, using a synthetic mixture with a proportion of 11:9:4 for acetic:propionic:butyric. Therefore, in the inhibitory threshold of $125 \mathrm{Cmmol}$ total volatile acidity, the concentration of each acid was $3.4 \mathrm{~g}$ acetic/L, $3.5 \mathrm{~g}$ propionic/L, and $1.8 \mathrm{~g}$ butyric/L, slightly higher than the concentration of butyric acid used in this study.

In addition, the final maximum PHA concentration reached in $3.5 \mathrm{~B}$ test is half of that achieved in the lower concentration tests $(1.5 \mathrm{~B}$ and $2.5 \mathrm{~B})$, indicating that PHA accumulation is not favored at high butyric acid concentrations. The maximum PHA concentrations were 225, 215, and $104 \mathrm{mg} / \mathrm{L}$ for $1.5 \mathrm{~B}, 2.5 \mathrm{~B}$, and $3.5 \mathrm{~B}$, respectively.

\subsubsection{Balanced valeric:butyric ratio assays $(3.0 \mathrm{~N}, 3.5 \mathrm{~N}$, and $5.0 \mathrm{~N}$ and Fig. $5 \mathrm{~d}, 5 \mathrm{e}$, and $5 \mathrm{f}$ )}

For balanced valeric:butyric ratio, a very different behavior is observed in each assay. The $3.0 \mathrm{~N}$ assay immediately started the degradation of all the VFAs (acetic, propionic, butyric, and valeric) at very high rate, reaching the maximum PHA production after only 3 days. These acids were depleted in reverse order of their initial concentrations. Furthermore, in $3.0 \mathrm{~N}$ and $3.5 \mathrm{~N}$ test, valeric and butyric acids were simultaneously consumed at the same time at a coincident rate.

However, in the assay $3.5 \mathrm{~N}$, the maximum PHA level was reached at day 5 and does not match with the complete consumption of all VFAs. As it can be seen in Fig. 5e, the maximum PHA production occurs when butyric and valeric acids were depleted on day 5, although there is still a residual acetic acid concentration. This time delay to reach maximum PHA production versus $3.0 \mathrm{~N}$ test is due to the apparition of an initial latency periods of 2 days for butyric and valeric consumption and 4 days for acetic acid. From day 4 , once the valeric and butyric acid concentrations were almost depleted, a sharp consumption of acetic acid occurred. However, its contribution to increasing the maximum of PHA production was minor.

In this sense, Wang et al. [23] have found that the use of valeric and butyric acids is preferential to the use of acetic and propionic acids even at low DO concentrations. In addition, Marang et al. [44] reported that butyric acid seems to be the preferred carbon source over acetic acid for PHB production in a study with sequential biological reactors (SBR) operated under feast-famine conditions where Plasticicumulans acidovorans was the predominant microorganism. The theoretical PHA production from butyric acid has a stoichiometric yield of $0.94 \mathrm{Cmol} \mathrm{PHB} / \mathrm{Cmol} \mathrm{HBu}$, which is $40 \%$ higher than the yield associated with acetic acid [45].

In summary, for balanced valeric:butyric ratio, the results have shown a delay in the maximum PHA production and the appearance of lag periods. These facts seem to indicate that the change in valeric:butyric proportion (high butyric to neutral balance) has made the system more sensitive to the increase of butyric acid concentration. This distortion could be observed in $3.5 \mathrm{~N}$ where initial butyric acid concentration $(568 \mathrm{mg} \mathrm{HBu} / \mathrm{L}$ ) was comprised between the butyric acid concentrations in $1.5 \mathrm{~B}(488 \mathrm{mg} \mathrm{HBu} / \mathrm{L})$ and $2.5 \mathrm{~B}(824 \mathrm{mg} \mathrm{HBu} / \mathrm{L})$ and clearly under the butyric acid level in 3.5B (1130 mg HBu/L). Therefore, the presence of important concentrations of valeric acid has negative effect on the PHA production.

Finally, about the effect of total acidity concentration on the PHA production, once again, when the acidity is increased up to $5 \mathrm{~g} / \mathrm{L}(5.0 \mathrm{~N})$, the consumption of acetic acid slows down with respect to the consumption of valeric and butyric acid, which again occurred simultaneously. As consequence, the final acetic consumption contributed to the delay of the PHA production. As it occurred in 3.5B, high total acidity concentrations induce a PHA production slower and minor. In this way, the increase in total acidity concentration has impaired the process, reaching 155, 127, and $48 \mathrm{mg} / \mathrm{L}$ of maximum PHA production for $3.0 \mathrm{~N}, 3.5 \mathrm{~N}$, and $5.0 \mathrm{~N}$ tests, respectively.

Although the initial butyric acid concentration is lower in $5.0 \mathrm{~N}(920 \mathrm{mg} / \mathrm{L})$ than in $3.5 \mathrm{~B}(1130 \mathrm{mg} / \mathrm{L})$, the cumulative effect of the presence of a high initial total volatile acidity concentration in $5.0 \mathrm{~N}$ has reduced the maximum PHA production to one third. This observation indicates that as the total volatile acidity increases the metabolism of PHA 

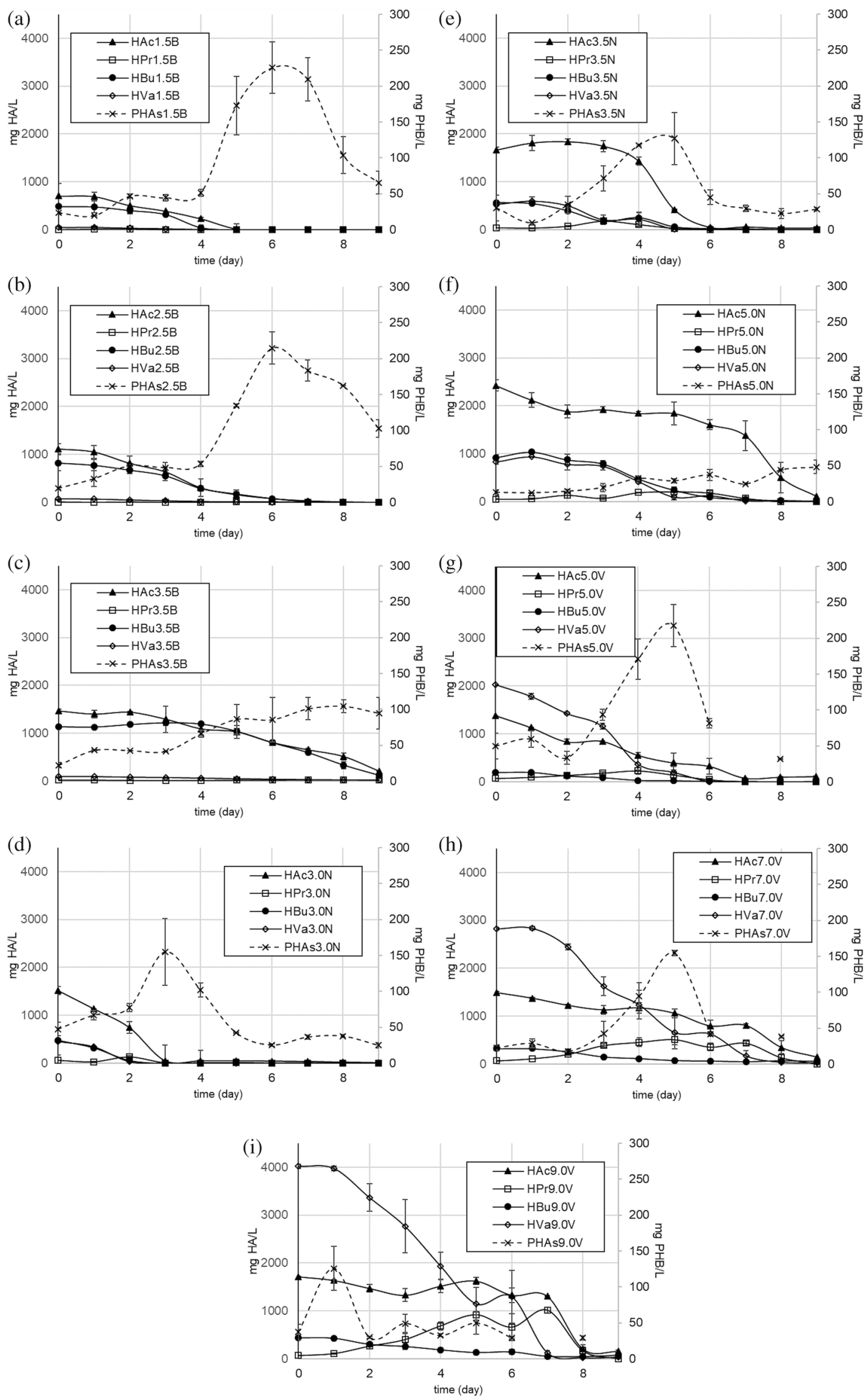
४Fig. 5 Evolutions of the individual VFAs (acetic, propionic, butyric, and valeric) expressed in $\mathrm{mg} / \mathrm{L}$ and PHA production expressed in $\mathrm{mg}$ $\mathrm{PHB} / \mathrm{L}$. a Assay $1.5 \mathrm{~B} ; \mathbf{b}$ assay $2.5 \mathrm{~B}$; c assay $3.5 \mathrm{~B}$; d assay $3.0 \mathrm{~N}$; e assay $3.5 \mathrm{~N} ; \mathbf{f}$ assay $5.0 \mathrm{~N} ; \mathbf{g}$ assay $5.0 \mathrm{~V} ; \mathbf{h}$ assay $7.0 \mathrm{~V} ; \mathbf{i}$ assay $9.0 \mathrm{~V}$

production is less favored [40-43]. However, is not clear the relative magnitude of the imparaing effect of valeric and butyric acids.

\subsubsection{High valeric assays $(5.0 \mathrm{~V}, 7.0 \mathrm{~V}$, and $9.0 \mathrm{~V}$ and Fig. $5 \mathrm{~g}$, $5 \mathrm{~h}$, and $5 \mathrm{i}$ )}

In this case, the tests were less sensitive to high volatile acidity concentrations. In $5.0 \mathrm{~V}$ test, which contained up to $2 \mathrm{~g}$ valeric/L, acetic and valeric acids were degraded rapidly, reaching the maximum PHA production on day 5. Nevertheless, this maximum is ahead of the total consumption of both acids.

This could be similar to previously discussed for the $3.5 \mathrm{~N}$ test, where the final acetic acid consumption was delayed from the maximum PHA production. Hence, the maximum PHA production seems to be decoupled to the complete consumption of both acids. In fact, it is remarkable that only in these high valeric concentrations, propionic acid concentrations reached $511 \mathrm{mg} / \mathrm{L}$ on day 5 for the $7.0 \mathrm{~V}$ test and $405-1015 \mathrm{mg} / \mathrm{L}$ in the period day 3 to day 7 in the $9.0 \mathrm{~V}$ test. In fact, this effect has been previously observed in $3.5 \mathrm{~N}$ and $5.0 \mathrm{~N}$ although with minor intensity.

It must be considered that the acidogenic effluent used to feed the inoculation reactor of PHA-producers microorganisms contained high butyric and acetic concentrations. The high butyric acid concentration required an adaptation period of the PHA-producing microbiota but, once adapted, the degradation of butyric acid occurs. However, the degradation of valeric acid seems to have resulted in lower PHA productivities. Figure 6 shows the degradation percentages of each individual acid after 6 days, showing the formation of propionic acid in those tests with a high initial proportion of valeric acid.

The formation of propionic acid, especially in high valeric:butyric ratio assays, shows the coexistence of a degradative metabolism of valeric acid non-related to the PHA production. The high concentration of valeric acid has allowed the development of this acidogenic degradative activity by means of $\beta$-oxidations that have subtracted carbon sources for the maximum PHA production. In fact, the maximum PHA production in the $9.0 \mathrm{~V}$ assay occurs after $24 \mathrm{~h}$ and, from this point on, the system started to degrade PHAs while metabolizing the most important fraction of valeric and acetic acids. The maximum PHA productions in $\mathrm{V}$ assays were 217,154 , and $126 \mathrm{mg} / \mathrm{L}$.

In summary, butyric acid appears to be the most easily metabolized VFAs by PHA producers according to the maximum PHA concentrations reached in each test, although dosing at concentrations below $1.1 \mathrm{~g} \mathrm{HBu} / \mathrm{L}$ is preferable. Acetic acid is completely degraded once the degradation of valeric and butyric acids has concluded, especially for tests with high concentrations of valeric acid. On the other hand, the presence of high concentrations of valeric acid seems to promote a parallel degradative pathway for propionic acid, leading to a diminishing of the PHA production capacity of the process.

\subsection{PHA yield}

The PHA yield should not be measured in terms of concentration, as the biomass concentration changes throughout the process due to cell growth. Therefore, the PHA production yields have been calculated by dividing the total PHA obtained by the VSS. In this case, the VSS were assumed to represent the amount of cell biomass in the assays.

Furthermore, this ratio (g PHA/g VSS) is a key factor for the PHA extraction stage since if its value is high the recovery of PHA (downstream industrial processes) is easier and cheaper [13]. Figure 7 shows the evolution of the PHA yield estimated in this way.

Table 2 shows the maximum values of the PHA yield (expressed as percentage) with an indication of the day on which they have been obtained. The average PHA yield values are also given for the period from the start of the test to the day when the maximum PHA production yield was reached. Additionally, Table 2 includes the values of the average daily rate (ADR) for PHA production. ADR represents the ratio between the maximum PHA yield of the process and the time required to reach it.

The ADR is a parameter that allows comparing the different conditions tested in order to select that leading to maximum PHA production in the minor time, which could be of industrial interest. Results of ADR in Table 2 show that better conditions are corresponding to the minor total volatile acidity concentration in each set of assays: $3.0 \mathrm{~N}$, $1.5 \mathrm{~B}$, and $5.0 \mathrm{~V}$.

Clearly, the lower acid concentration assays $(1.5 \mathrm{~B}, 3.0 \mathrm{~N}$, and $5.0 \mathrm{~V}$ ) offered the best yields within each valeric:butyric ratio. As the acid concentration increases in each ratio, the MMC were less capable of directing carbon consumption towards PHA production. It is noticeably evident (assays $3.5 \mathrm{~B}, 5.0 \mathrm{~N}$, and $9.0 \mathrm{~V}$ ) that the ADR of PHA production is visibly affected by the high butyric and valeric concentration. However, the sensitivity to each acid is not the same. The high butyric acid assays at low concentrations of total volatile acidity (1.5B and 2.5B tests) gave better PHA yields (23.0 and $17.1 \%$, respectively) than the equivalent tests with high valeric:butyric ratio. Thus, in the last case $(5.0 \mathrm{~V}$ and $7.0 \mathrm{~V}$ tests), the maximum PHA yield reached was 14.2 and $8.5 \%$ despite the butyric acid concentration was similar or even lower than in $1.5 \mathrm{~B}$. 


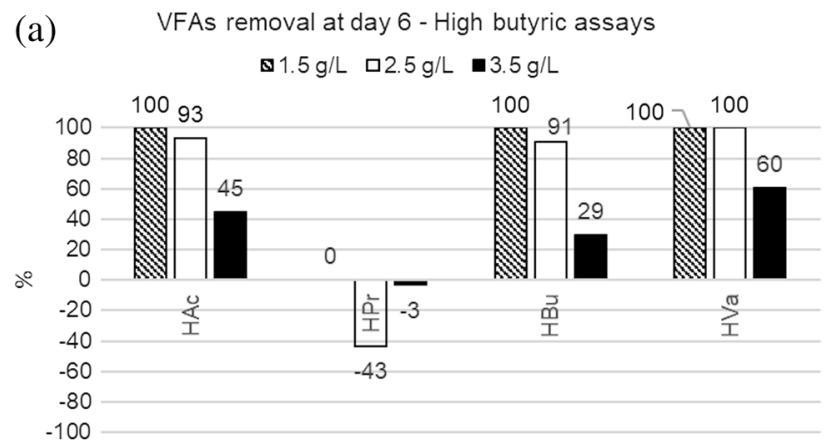

(b)

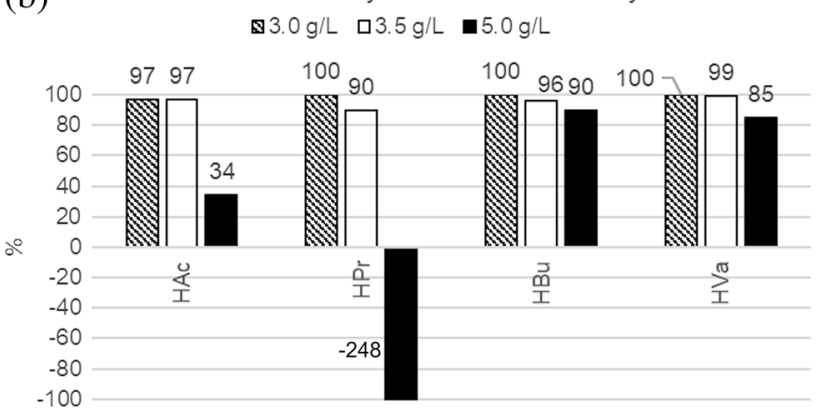

(c)

$$
\text { VFAs removal at day } 6 \text { - High valeryc assays }
$$

$\$ 5.0 \mathrm{~g} / \mathrm{L} \quad \square 7.0 \mathrm{~g} / \mathrm{L} \quad \mathbf{m} 9.0 \mathrm{~g} / \mathrm{L}$

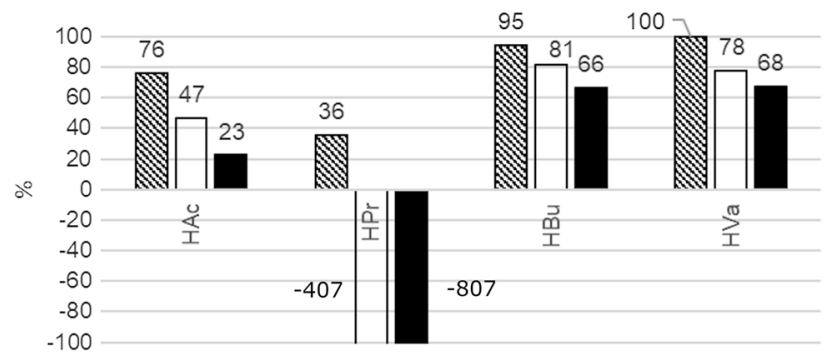

Fig. 6 Individual VFAs removal percentage at day 6. a Assays with $1: 10$ valeric:butyric ratio; b assays with $1: 1$ valeric:butyric ratio; c assays with 10:1 valeric:butyric ratio

Table 3 shows data from different authors of the maximum accumulation capacity for PHA production, using VFAs, by MMC. As it can be seen, the PHA yield values are between 23 and 53\%. The results obtained in this work are in the lower range, although they are practically the same as those obtained by other authors who have worked with VFAs with MMC.

PHA titer values are highly dependent on the operational conditions and configuration of the process for PHA production from VFAs by MMC. Ciesielski and Przybylek [51] observed PHA titers between 227.8 (acetic as feeding) and $673 \mathrm{mg} / \mathrm{L}$ (propionic as feeding) in batch reactors inoculated with activated sludge from wastewater treatment plant. In the present study, propionic was always under $70 \mathrm{mg} / \mathrm{L}$ in feeding while acetic acid was fed between 704 and $2426 \mathrm{mg} / \mathrm{L}$ (a)

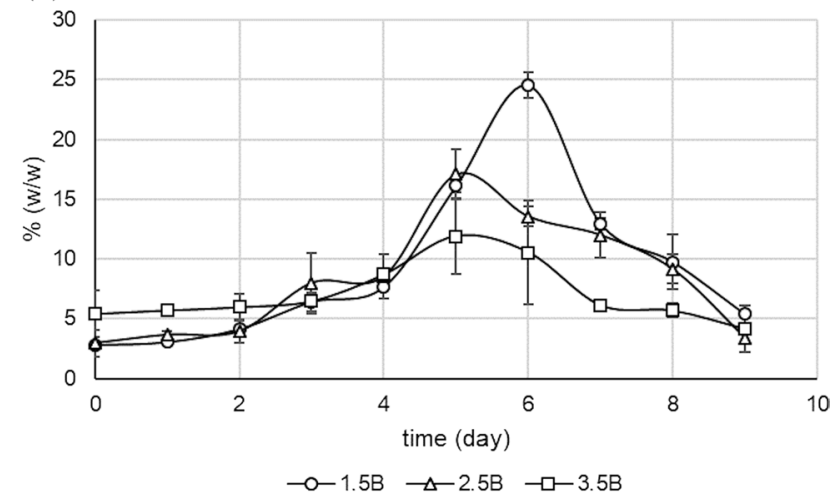

(b)

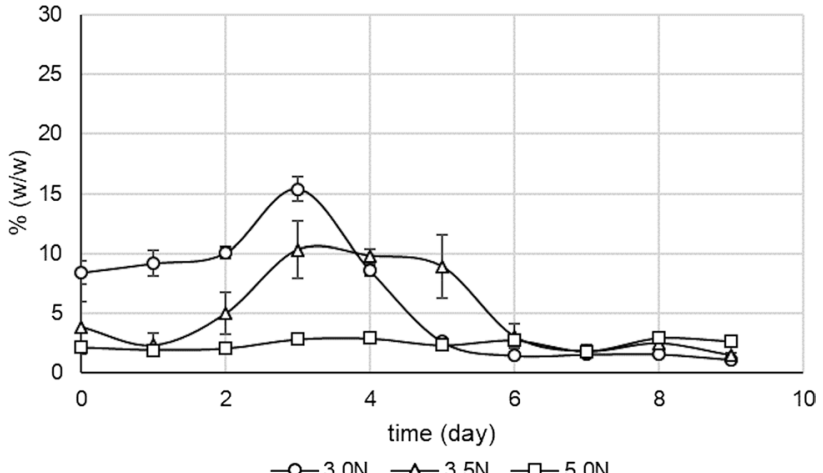

(c)

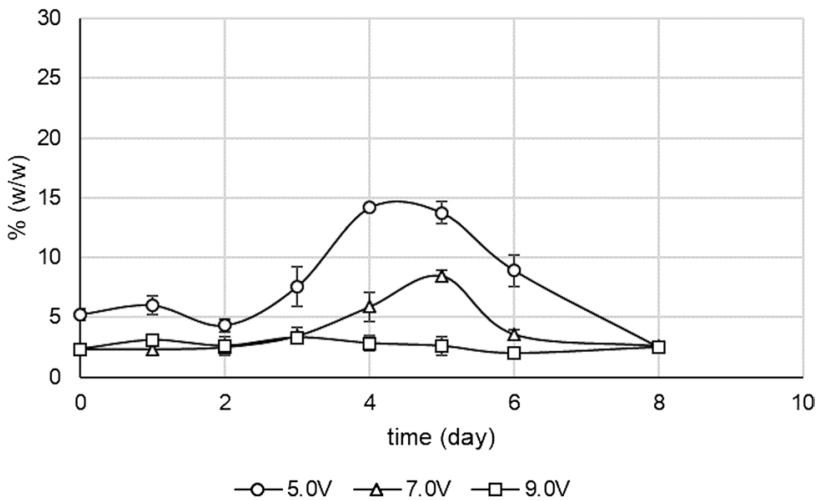

Fig. 7 Evolution of the PHA yield at dry basis expressed as percentage. a Assays with 1:10 valeric:butyric ratio; b assays with 1:1 valeric:butyric ratio; $\mathbf{c}$ assays with 10:1 valeric:butyric ratio

and the PHA titer was over $200 \mathrm{mg} / \mathrm{L}$ just in $1.5 \mathrm{~B}$ and $2.5 \mathrm{~B}$ assays where acetic was in lower levels but higher butyric concentrations where supplied. It is should be remarked that butyric acid follows the same metabolic pathway than acetic acid for PHA production [52]. However, PHA titer from MMC could be considerably higher under most favorable conditions as it can be seen in the study of Perez-Zabaleta et al. [16]. 
Table 2 Maximum PHA yield (expressed as percentage), time to reach the maximum PHA yield, and ADR for PHA production

\begin{tabular}{llll}
\hline Assay & $\begin{array}{l}\text { Maximum PHA } \\
\text { yield (\%) }\end{array}$ & Day & $\begin{array}{l}\text { ADR for PHA } \\
\text { production }(\%) \\
\text { day) }\end{array}$ \\
\hline $1.5 \mathrm{~B}$ & 23.0 & 6 & 4.08 \\
$2.5 \mathrm{~B}$ & 17.1 & 5 & 3.42 \\
$3.5 \mathrm{~B}$ & 11.9 & 5 & 2.38 \\
$3.0 \mathrm{~N}$ & 14.0 & 3 & 5.13 \\
$3.5 \mathrm{~N}$ & 10.3 & 3 & 3.43 \\
$5.0 \mathrm{~N}$ & 3.0 & 8 & 0.38 \\
$5.0 \mathrm{~V}$ & 14.2 & 4 & 3.55 \\
$7.0 \mathrm{~V}$ & 8.5 & 5 & 1.70 \\
$9.0 \mathrm{~V}$ & 3.3 & 3 & 1.10 \\
\hline
\end{tabular}

${ }^{1} \mathrm{ADR}$ has been calculated as the ratio between the maximum PHA yield (\%) and the number of days that have been needed to reach the maximum for PHA production

\subsection{Effect of total volatile acidity and valeric:butyric ratio on maximum PHA yield}

The results obtained for the maximum PHA production yield indicated in Table 2 can be related to the two main variables analyzed in this study: the concentration of total volatile acidity fed to the system and the valeric:butyric ratio.

Thus, representing the maximum values of PHA production obtained in each test versus the initial total acidity (expressed as acetic acid), Fig. 8a is obtained. In this figure, it can be seen that the results corresponding to the tests with a ratio of butyric:valeric of 10:1 (B) and 1:1 (N) have the same trend, while the tests corresponding to the ratio 1:10 (V) show a differentiated behavior. In all the cases, the trends observed are fitted to linear correlations. In Fig. 8b and $8 \mathrm{c}$, the maximum PHA yields are plotted versus the initial concentrations of butyric and valeric acids, respectively. These last two graphs clearly show that the data also cluster in linear distributions for each of the butyric:valeric ratios tested.

As it can be seen in Fig. 8, the evolutions of the maximum PHA production yield adopt a distribution with respect to the initial acid concentrations that clearly differentiate the set of tests carried out with each butyric:valeric ratio. In all the cases, the observed evolution indicates that the maximum PHA production yield decreases as the initial concentration of the considered acid increases. This implies that the VFAs, although they are the substrate used by the microorganisms in the generation of PHA, have an inhibitory effect on the process. This effect has been observed by other authors [40-43, 53].

Concretely, Tamang et al. [53] have estimated the inhibitory effect of VFAs in some industrial wastewaters between 7.1 and $82.1 \mathrm{mM}$ by means of measuring the diminishing in the specific oxygen uptake rate (SOUR) over diluted samples of wastewaters. With dairy wastewaters, the SOUR decrease by $83 \%$ when the total volatile acidity concentration was incremented from 4 to $15.7 \mathrm{mM}$.

As it can be seen in Fig. 8, the different sets of data have been fitted by linear regression. Table 4 shows the representative parameters of each linear adjustment. Letters B, N, and $\mathrm{V}$ in the column named as ratio indicate the set of points used for fitting according to the nomenclature defined in Table 1. The slope is related to the inhibitory effect of each acid, as it was previously commented. The y-interception corresponds to the maximum PHA yield value achievable under the operating conditions. These values are in the same range as described by other authors $[24,54-56]$ for the maximum PHA accumulation in the cell (expressed in \%) when using MMC and carbon sources corresponding to wastes and not pure compounds and well-defined media.

Table 3 Comparison of the obtained results in this study with the literature data for PHA production from VFAs by MMC in terms of maximum accumulation capacity, PHA titer, and PHA yield based on VFA fed

\begin{tabular}{|c|c|c|c|}
\hline Carbon source & $\begin{array}{l}\text { Maximum PHA } \\
\text { yield }(\%)\end{array}$ & $\begin{array}{l}\text { Maximum PHA } \\
\text { titer }(\mathrm{g} / \mathrm{L})\end{array}$ & Ref \\
\hline VFAs from acidogenic fermentation ( $30 \%$ food waste $+70 \%$ primary sewage sludge) & 44 & 2.4 & [16] \\
\hline Municipal wastewater supplemented with acetic acid & 30 & - & {$[38]$} \\
\hline Acetic acid & 40 & - & [46] \\
\hline VFAs from the acidogenic fermentation of paper mill wastewater & 48 & - & [47] \\
\hline VFAs from the acidogenic fermentation of food waste & 24 & - & [48] \\
\hline Synthetic waste (VFAs) & 53 & - & [49] \\
\hline VFAs from heat pretreated sludge & 24 & - & {$[50]$} \\
\hline \multirow[t]{2}{*}{ Synthetic waste } & 31 & 0.23 & {$[51]$} \\
\hline & 30 & 0.67 & \\
\hline Synthetic waste (VFAs) & 23 & 0.23 & This work \\
\hline
\end{tabular}




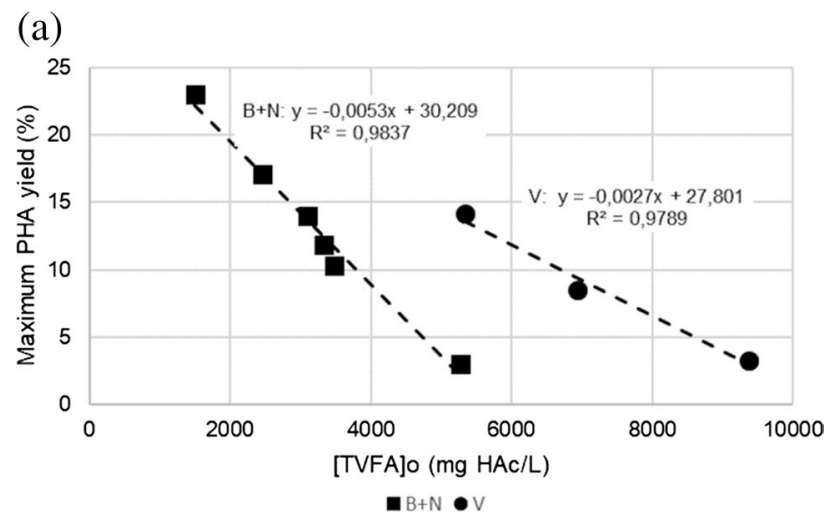

(b)

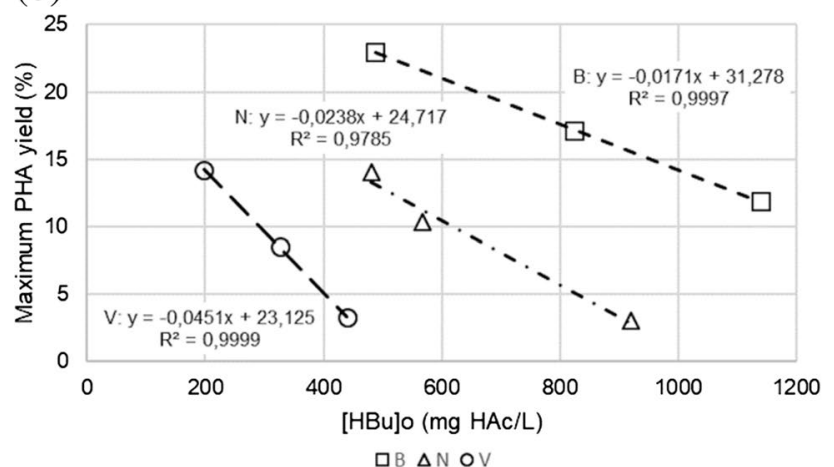

(c)

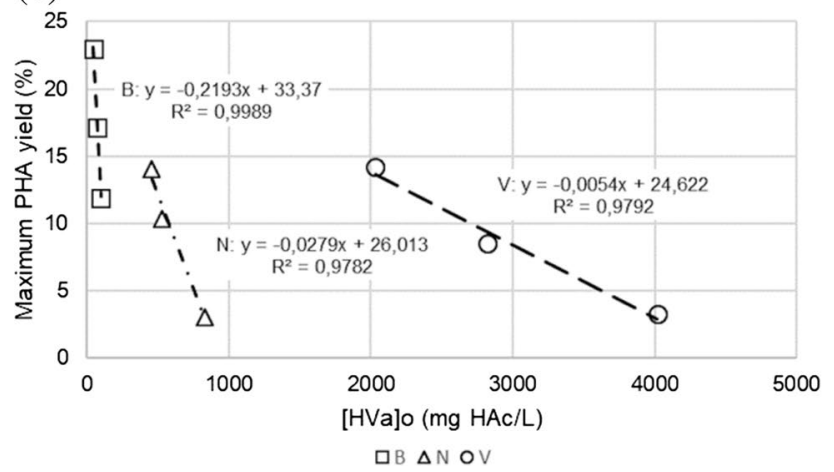

Fig. 8 Maximum PHA yield at dry basis expressed in percentage versus initial concentration of a total volatile acidity in mg HAc/L, b butyric acid in $\mathrm{mg} \mathrm{HBu} / \mathrm{L}$, and $\mathbf{c}$ valeric acid in $\mathrm{mg} \mathrm{HVa/L}$. The lines represent the linear regression fittings

\section{Conclusions}

Based on the results obtained in this study and the discussion carried out in the previous section, the following conclusions can be drawn:

The PHA producers were capable to metabolize all the mixtures of VFAs tested, but the PHA production yield was clearly affected by the initial total volatile acidity concentration, as well as by feeding composition in terms of butyric:valeric ratio.

As the total volatile acidity concentration increases, the system is less able to direct carbon consumption towards PHA production. High butyric acid assays at low total volatile acidity concentrations give better PHA yields than equivalent assays with high valeric acid concentrations.

For assays with high concentrations of butyric and valeric acids, it is required the previous degradation of them to the beginning of the acetic acid degradation. Moreover, the presence of high concentrations of valeric acid seems to promote a parallel degradative pathway towards propionic acid that would decrease the PHA yield.

The maximum PHA yield reached in this study was $23 \%$ (w/w) corresponding to the test carried out with an initial total volatile acidity concentration of $1.5 \mathrm{~g} \mathrm{HAc} / \mathrm{L}$ and a butyric:valeric ratio of 10:1. However, the ADR for PHA production indicates that the best conditions correspond to the test with $3.0 \mathrm{~g} \mathrm{HAc} / \mathrm{L}$ and butyric:valeric ratio of 1:1.

The linear regression of the maximum PHA production yield achieved in the different tests performed against the initial acid concentration used allows determining that the threshold value of the maximum PHA in the system is in the range $23-33 \%(\mathrm{w} / \mathrm{w})$.

Acknowledgements The authors would like to thank the Agrifood Campus of International Excellence (ceiA3).

Author contribution Conceptualization, methodology, software, validation, formal analysis, investigation, resources, data curation, writingoriginal draft preparation, writing-review and editing, visualization, supervision, project administration, and funding acquisition were developed through equal contributions of all authors. All authors have read and agreed to the published version of the manuscript.
Table 4 Parameters from the linear regression of maximum PHA yield versus the initial acid concentration (total volatile acidity, butyric, and valeric)

\begin{tabular}{lllll}
\hline Fitting & Ratio & Y-intercept $(\%)$ & Slope $(\% / \mathrm{mg} / \mathrm{L})$ & $R^{2}$ \\
\hline PHA(\%) vs initial total VFAs & B $+\mathrm{N}$ & 30.209 & -0.0053 & 0.9837 \\
& V & 27.801 & -0.0027 & 0.9789 \\
PHA(\%) vs initial HBu & B & 31.278 & -0.0171 & 0.9997 \\
& N & 24.717 & -0.0238 & 0.9785 \\
PHA(\%) vs initial HVa & V & 23.125 & -0.0451 & 0.9999 \\
& B & 33.370 & -0.2193 & 0.9989 \\
& N & 26.013 & -0.0279 & 0.9782 \\
& V & 24.622 & -0.0054 & 0.9792 \\
\hline
\end{tabular}


Funding Open Access funding provided thanks to the CRUE-CSIC agreement with Springer Nature. This research was supported by the project CTM2016-79071-R (Spanish Ministry of Economy, Industry and Competitiveness) and financed by the Spanish State Research Agency ("Agencia Estatal de Investigación" (AEI)) and by the European Regional Development Fund (ERDF) and by grant from the Program for the Promotion and Impulse of Research and Transfer of the University of Cadiz (Ref: IRTP04_UCA).

Availability of data and material Supported by authors declaration.

Code availability Not applicable.

\section{Declarations}

Conflict of interest The authors declare no competing interests.

Open Access This article is licensed under a Creative Commons Attribution 4.0 International License, which permits use, sharing, adaptation, distribution and reproduction in any medium or format, as long as you give appropriate credit to the original author(s) and the source, provide a link to the Creative Commons licence, and indicate if changes were made. The images or other third party material in this article are included in the article's Creative Commons licence, unless indicated otherwise in a credit line to the material. If material is not included in the article's Creative Commons licence and your intended use is not permitted by statutory regulation or exceeds the permitted use, you will need to obtain permission directly from the copyright holder. To view a copy of this licence, visit http://creativecommons.org/licenses/by/4.0/.

\section{References}

1. Khatami K, Perez-Zabaleta M, Owusu-Agyeman I, Cetecioglu Z (2021) Waste to bioplastics: how close are we to sustainable polyhydroxyalkanoates production? Waste Manag 119:374-388. https://doi.org/10.1016/j.wasman.2020.10.008

2. Al Battashi H, Al-Kindi S, Gupta VK, Sivakumar N (2021) Polyhydroxyalkanoate (PHA) production using volatile fatty acids derived from the anaerobic digestion of waste paper. J Polym Environ 29:250-259. https://doi.org/10.1007/s10924-020-01870-0

3. Dietrich K, Dumont MJ, Del Rio LF, Orsat V (2017) Producing PHAs in the bioeconomy -towards a sustainable bioplastic. Sustain Prod Consum 9:58-70. https://doi.org/10.1016/j.spc.2016.09. 001

4. Raza ZA, Abid S, Banat IM (2018) Polyhydroxyalkanoates: characteristics, production, recent developments and applications. Int Biodeterior Biodegrad 126:45-56. https://doi.org/10.1016/j.ibiod. 2017.10.001

5. Koller M (2018) Biodegradable and biocompatible polyhydroxyalkanoates (PHA): auspicious microbial macromolecules for pharmaceutical and therapeutic applications. Molecules 23:362. https://doi.org/10.3390/molecules23020362

6. Folino A, Karageorgiou A, Calabrò PS, Komilis D (2020) Biodegradation of wasted bioplastics in natural and industrial environments: a review. Sustainability 12:6030. https://doi.org/10.3390/ su12156030

7. De Donno NL, Moreno Sayavedra S, Rene ER (2021) Polyhydroxyalkanoate (PHA) production via resource recovery from industrial waste streams: a review of techniques and perspectives. Bioresour Technol 331:124985. https://doi.org/10.1016/j.biortech. 2021.124985
8. Kourmentza C, Plácido J, Venetsaneas N, Burniol-Figols A, Varrone C, Gavala HN, Reis MAM (2017) Recent advances and challenges towards sustainable polyhydroxyalkanoate (PHA) production. Bioengineering (Basel) 4(2):55. https://doi.org/10.3390/ bioengineering 4020055

9. Sirohia R, Pandey JP, Gaur VK, Gnansounou E, Sindhu R (2020) Critical overview of biomass feedstocks as sustainable substrates for the production of polyhydroxybutyrate (PHB). Bioresour Technol 311:123536. https://doi.org/10.1016/j.biortech.2020. 123536

10. Pagliano G, Galletti $\mathrm{P}$, Samorì C, Zaghini A, Torri C (2021) Recovery of polyhydroxyalkanoates from single and mixed microbial cultures: a review. Front Bioeng Biotechnol 9:624021. https:// doi.org/10.3389/fbioe.2021.624021

11. Mannina G, Presti D, Montiel-Jarillo G, Carrera J, Suárez-Ojeda ME (2020) Recovery of polyhydroxyalkanoates (PHAs) from wastewater: a review. Bioresour Technol 297:122478. https://doi. org/10.1016/j.biortech.2019.122478

12. Nguyenhuynh T, Yoon LW, Chow YH, Chua ASM (2021) An insight into enrichment strategies for mixed culture in polyhydroxyalkanoate production: feedstocks, operating conditions and inherent challenges. Chem Eng J 420:130488. https://doi.org/10. 1016/j.cej.2021.130488

13. Mannina G, Presti D, Montiel-Jarillo G, Suárez-Ojeda ME (2019) Bioplastic recovery from wastewater: a new protocol for polyhydroxyalkanoates (PHA) extraction from mixed microbial cultures. Bioresour Technol 282:361-369. https://doi.org/10.1016/j.biort ech.2019.03.037

14. Morgan-Sagastume F, Bengtsson S, De Grazia J, Alexandersson T, Quadri L, Johansson P, Magnusson P, Werker A (2020) Mixedculture polyhydroxyalkanoate (PHA) production integrated into a food-industry effluent biological treatment: a pilot-scale evaluation. J Environ Chem Eng 8(6):104469. https://doi.org/10.1016/j. jece.2020.104469

15. Koller M, Maršálek L, Dias MMS, Braunegg G (2017) Producing microbial polyhydroxyalkanoate (PHA) biopolyesters in a sustainable manner. New Biotechnol 37:24-38. https://doi.org/10.1016/j. nbt.2016.05.001

16. Perez-Zabaleta M, Atasoy M, Khatami K, Eriksson E, Cetecioglu $\mathrm{Z}$ (2021) Bio-based conversion of volatile fatty acids from waste streams to polyhydroxyalkanoates using mixed microbial cultures. Bioresour Technol 323:124604. https://doi.org/10.1016/j.biortech. 2020.124604

17. Szacherska K, Oleskowicz-Popiel P, Ciesielski S, MozejkoCiesielska J (2021) Volatile fatty acids as carbon sources for polyhydroxyalkanoates production. Polymers (Basel) 13:321. https:// doi.org/10.3390/polym13030321

18. Dietrich K, Dumont MJF, Del Rio L, Orsat V (2019) Sustainable PHA production in integrated lignocellulose biorefineries. New Biotechnol 49:161-168. https://doi.org/10.1016/j.nbt.2018.11.004

19. Angeriz-Campoy R, Fdez-Güelfo LA, Álvarez-Gallego CJ, Romero-García LI (2017) Inhibition of the hydrolytic phase in the production of biohydrogen by dark fermentation of organic solid waste. Energy Fuels 31(7):7176-7184. https://doi.org/10. 1021/acs.energyfuels. 7 b00847

20. Wang J, Wan W (2009) Factors influencing fermentative hydrogen production: a review. Int J Hydrog Energy 34:799-811. https://doi. org/10.1016/j.ijhydene.2008.11.015

21. Jiang Y, Hebly M, Kleerebezem R, Muyzer G, van Loosdrecht MCM (2011) Metabolic modelling of mixed substrate uptake for polyhydroxyalkanoate (PHA) production. Water Res 45(3):1309_ 1321. https://doi.org/10.1016/j.watres.2010.10.009

22. Gómez-Quiroga X, Aboudi K, Fernández-Güelfo LA, ÁlvarezGallego CJ, Romero-García LI (2021) Thermophilic anaerobic co-digestion of exhausted sugar beet pulp with cow manure to 
boost the performance of the process: the effect of manure proportion. Water 13:67. https://doi.org/10.3390/w13010067

23. Wang X, Oehmen A, Freitas EB, Carvalho G, Reis MAM (2017) The link of feast-phase dissolved oxygen (DO) with substrate competition and microbial selection in PHA production. Water Res 112:269-278. https://doi.org/10.1016/j.watres.2017.01.064

24. Albuquerque MGE, Martino V, Pollet E, Avérous L, Reis MAM (2011) Mixed culture polyhydroxyalkanoate (PHA) production from volatile fatty acid (VFA)-rich streams: effect of substrate composition and feeding regime on PHA productivity, composition and properties. J Biotechnol 151(1):66-76. https://doi.org/10. 1016/j.jbiotec.2010.10.070

25 American Public Health Association (APHA) (2005) Standard method for examination of water and wastewater. APHA, AWWA, WPCF, Washington

26. Amulya K, Venkateswar Reddy M, Venkata Mohan S (2014) Acidogenic spent wash valorization through polyhydroxyalkanoate (PHA) synthesis coupled with fermentative biohydrogen production. Bioresour Technol 158:336-342. https://doi.org/10.1016/j. biortech.2014.02.026

27. Venkateswar Reddy M, Amulya K, Rohit MV, Sarma PM, Venkata Mohan S (2014) Valorization of fatty acid waste for bioplastics production using Bacillus tequilensis: integration with darkfermentative hydrogen production process. Int J Hydrog Energy 39(14):7616-7626. https://doi.org/10.1016/j.ijhydene.2013.09. 157

28. Aboudi K, Álvarez-Gallego CJ, Romero-García LI (2016) Evaluation of methane generation and process stability from anaerobic codigestion of sugar beet by-product and cow manure. J Biosci Bioeng 121(5):566-572. https://doi.org/10.1016/j.jbiosc.2015.10.005

29. Saba F, Papizadeh M, Khansha J, Sedghi M, Rasooli M, Amoozegar MA, Soudi MR, ShahzadehFazeli SA (2016) A rapid and reproducible genomic DNA extraction protocol for sequencebased identification of Archaea, Bacteria, Cyanobacteria, Diatoms, Fungi, and Green Algae. J Med Bacteriol 5(3-4):22-28. https://jmb.tums.ac.ir/index.php/jmb/article/view/252

30. Davolos D, Pietrangeli B (2009) Molecular and phylogenetic analysis on bacterial strains isolated from a PAHs wastewater treatment plant. Curr Res Top Appl Microbiol Microb Biotechnol 2009:313-316. https://doi.org/10.1142/9789812837554_0066

31. Zhang Z, Schwartz S, Wagner L, Miller W (2000) A greedy algorithm for aligning DNA sequences. J Comput Biol 7(1-2):203214. https://doi.org/10.1089/10665270050081478

32. Samrot AV, Avinesh RB, Sukeetha SD, Senthilkumar P (2011) Accumulation of poly[(R)-3-hydroxyalkanoates] in Enterobacter cloacae SU-1 during growth with two different carbon sources in batch culture. Appl Biochem Biotechnol 163(1):195-203. https:// doi.org/10.1007/s12010-010-9028-7

33. Matsumoto K, Kitagawa K, Jo SJ, Song Y, Taguchi S (2011) Production of poly(3-hydroxybutyrate-co-3-hydroxyvalerate) in recombinant Corynebacterium glutamicum using propionate as a precursor. J Biotechnol 152(4):144-146. https://doi.org/10.1016/j. jbiotec.2010.07.031

34. Berezina N, Yada B (2016) Improvement of the poly(3-hydroxybutyrate-co-3-hydroxyvalerate) (PHBV) production by dual feeding with levulinic acid and sodium propionate in Cupriavidus necator. New Biotechnol 33(1):231-236. https://doi.org/10. 1016/j.nbt.2015.06.002

35. Koller M, Salerno A, Strohmeier K, Schober S, Mittelbach M, Illieva V, Chiellini E, Braunegg G (2014) Novel precursors for production of 3-hydroxyvalerate-containing poly[(R)-hydroxyalkanoates]. Biocatal Biotransformation 32(3):161-167. https://doi. org/10.3109/10242422.2014.913580

36. Shivakumar S (2012) Accumulation of poly (3-hydroxybutyrate) by Microbacterium barkeri DSM 20145. Turk J Biol 36:225-232. https://doi.org/10.3906/biy-1103-2
37. Osman Y, AbdElrazak A, Khater W (2016) Microbial biopolymer production by Microbacterium WA81 in batch fermentation. Egypt J Basic Appl Sci 3(3):250-262. https://doi.org/10.1016/j. ejbas.2016.05.001

38. Chua ASM, Takabatake H, Satoh H, Mino T (2003) Production of polyhydroxyalkanoates (PHA) by activated sludge treating municipal wastewater: effect of $\mathrm{pH}$, sludge retention time (SRT), and acetate concentration in influent. Water Res 37(15):3602-3611. https://doi.org/10.1016/S0043-1354(03)00252-5

39. Możejko-Ciesielska J, Marciniak P, Szacherska K (2019) Polyhydroxyalkanoates synthesized by Aeromonas species: trends and challenges. Polymers (Basel) 11(8):1328. https://doi.org/10.3390/ polym 11081328

40. Albuquerque GE, Concas S, Bengtsson S, Reis MAM (2010) Mixed culture polyhydroxyalkanoates production from sugar molasses: the use of a 2-stage CSTR system for culture selection. Bioresour Technol 101(18):7112-7122. https://doi.org/10.1016/j. biortech.2010.04.019

41. Akaraonye E, Keshavarz T, Roy I (2010) Production of polyhydroxyalkanoates: the future green materials of choice. J Chem Technol Biotechnol 85:732-743. https://doi.org/10.1002/jctb. 2392

42. Morgan-Sagastume F, Karlsson A, Johansson P, Pratt S, Boon N, Lant P, Werker A (2010) Production of polyhydroxyalkanoates in open, mixed cultures from a waste sludge stream containing high levels of soluble organics, nitrogen and phosphorus. Water Res 44(18):5196-5211. https://doi.org/10.1016/j.watres.2010.06.043

43. Wang J, Yue ZB, Sheng GP, Yu HQ (2010) Kinetic analysis on the production of polyhydroxyalkanoates from volatile fatty acids by Cupriavidus necator with a consideration of substrate inhibition, cell growth, maintenance, and product formation. Biochem Eng J 49(3):422-428. https://doi.org/10.1016/j.bej.2010.02.005

44. Marang L, Jiang Y, van Loosdrecht MCM, Kleerebezem R (2013) Butyrate as preferred substrate for polyhydroxybutyrate production. Bioresour Technol 142:232-239. https://doi.org/10.1016/j. biortech.2013.05.031

45. Shi H, Shiraishi M, Shimizu K (1997) Metabolic flux analysis for biosynthesis of poly( $\beta$-hydroxybutyric acid) in Alcaligenes eutrophus from various carbon sources. J Ferment Bioeng 84(6):579587. https://doi.org/10.1016/S0922-338X(97)81915-0

46. Beun J, Dircks K, Van Loosdrecht M, Heijnen J (2002) Polyhydroxybutyrate metabolism in dynamically fed mixed microbial cultures. Water Res 36:1167-1180. https://doi.org/10.1016/ S0043-1354(01)00317-7

47. Bengtsson S, Werker A, Christensson M, Welander T (2008) Production of polyhy-droxyalkanoates by activated sludge treating a paper mill wastewater. Bioresour Technol 99(3):509-516. https:// doi.org/10.1016/j.biortech.2007.01.020

48. Amulya K, Jukuri S, Venkata Mohan S (2015) Sustainable multistage process for enhanced productivity of bioplasticsfrom waste remediation through aerobic dynamic feeding strategy: process integration for up-scaling. Bioresour Technol 188:231-239. https://doi.org/10.1016/j.biortech.2015.01.070

49. Palmeiro-Sánchez T, Fra-Vázquez A, Rey-Martínez N, Campos JL, Mosquera-Corral A (2016) Transient concentrations of $\mathrm{NaCl}$ affect the PHA accumulation in mixed microbial culture. J Hazard Mater 306:332-339. https://doi.org/10.1016/j.jhazmat.2015.12. 032

50. Liao Q, Gao M, Ran Y, Gao M, She Z, Zhao Y, Liu Y (2018) Optimization of polyhydroxyalkanoates (PHA) synthesis with heat pretreated waste sludge. Waste Manag 82:15-25. https://doi. org/10.1016/j.wasman.2018.10.019

51. Ciesielski S, Przybylek G (2014) Volatile fatty acids influence on the structure of microbial communities producing PHAs. Braz J Microbiol 45(2):395-402. https://doi.org/10.1590/S1517-83822 014000200005 
52. Kumar M, Rathour R, Singh R, Sun Y, Pandey A, Gnansounou E, Lin KYA, Tsang DCW, Thakur IS (2020) Bacterial polyhydroxyalkanoates: opportunities, challenges, and prospects. J Clean Prod 263:121500. https://doi.org/10.1016/j.jclepro.2020.121500

53 Tamang P, Arndt C, Bruns-Hellberg J, Nogueira R (2021) Polyhydroxyalkanoates production from industrial wastewaters using a mixed culture enriched with Thauera sp.: inhibitory effect of the wastewater matrix. Environ Technol Innov 21:101328. https://doi. org/10.1016/j.eti.2020.101328

54. Bengtsson S, Pisco AR, Reis MAM, Lemos PC (2010) Production of polyhydroxyalkanoates from fermented sugar cane molasses by a mixed culture enriched in glycogen accumulating organisms. J Biotechnol 145(3):253-263. https://doi.org/10.1016/j.jbiotec. 2009.11.016
55. Albuquerque MGE, Eiroa M, Torres C, Nunes BR, Reis MAM (2007) Strategies for the development of a side stream process for polyhydroxyalkanoate (PHA) production from sugar cane molasses. J Biotechnol 130(4):411-421. https://doi.org/10.1016/j.jbiot ec.2007.05.011

56. Mengmeng C, Hong C, Qingliang Z, Shirley SN, Jie R (2009) Optimal production of polyhydroxyalkanoates (PHA) in activated sludge fed by volatile fatty acids (VFAs) generated from alkaline excess sludge fermentation. Bioresour Technol 100(3):1399-1405. https://doi.org/10.1016/j.biortech.2008.09.014

Publisher's note Springer Nature remains neutral with regard to jurisdictional claims in published maps and institutional affiliations. 